\title{
Transformation of Streptococcus sanguis to Intrinsic Penicillin Resistance
}

\author{
By EDWARD T. ZITO† AND LOLITA DANEO-MOORE* \\ Department of Microbiology and Immunology, Temple University School of Medicine, \\ Philadelphia, PA 19140, USA
}

(Received 26 January 1988)

\begin{abstract}
A series of step-level penicillin-resistant derivatives of Streptococcus sanguis V288 (Challis) were obtained through successive genetic transformations. The DNA donor used was a laboratoryderived, penicillin-resistant multistep mutant of the recipient strain. Detection of the penicillinbinding proteins (PBPs) of wild-type and transformants revealed five major PBPs. While it was found that $S$. sanguis can acquire intrinsic resistance in a stepwise manner and the mechanism was similar to those of some other organisms (changes in penicillin-binding protein affinity and/or in extent of penicillin binding), multiple-PBP changes accompanied a single step-level of resistance. All of the PBPs showed varying degrees of decreased affinity for $\left[{ }^{3} \mathrm{H}\right]$ benzylpenicillin with increasing penicillin resistance. Of these, the consistent, dramatic and progressive decrease of PBP 4 binding was most notable. After an initial decrease at the first step-level of resistance, PBP 5 was restored to wild-type levels, indicating a possible important role in survival. Genetic linkage of the first two step-levels of resistance was demonstrated by examination of transformation frequencies and by hit-kinetics experiments. A convenient method is described for the quantitative comparison of fluorographs containing PBPs with a wide range of affinities for penicillin.
\end{abstract}

\section{INTRODUCTION}

Penicillin-binding proteins (PBPs), bacterial membrane components that covalently bind penicillin and other $\beta$-lactam antibiotics, have in many cases been found to be enzymes involved in cell wall synthesis, assembly and maintenance (for reviews, see Blumberg \& Strominger, 1974; Waxman \& Strominger, 1983). It is generally considered that the $\beta$-lactam class of antibiotics exerts its primary effects through the inhibition of one or more of these enzymic activities. PBPs (three to nine in number) have been found in all bacterial species examined thus far.

Resistance to penicillin usually occurs through one of the following mechanisms: $(a)$ alteration of a cellular membrane to reduce permeability (generally occurring only in Gramnegative organisms); $(b)$ acquisition of a $\beta$-lactamase (hydrolysing enzyme); and $(c)$ alterations in the $\beta$-lactam targets (presumably one or more of the PBPs) (Dougherty, 1984). The alterations in PBPs are such that the affinity of these proteins for a radiolabelled $\beta$-lactam has changed, the quantity of a PBP has changed, or the mobility (apparent molecular mass) has changed as measured by SDS-PAGE fluorography (Spratt, 1977).

While intrinsic resistance in Gram-negative bacteria is in most cases due to inefficient penetration of the antibiotic through the cell membrane (Zimmerman, 1980; Spratt, 1983), Gram-positive bacteria do not possess such a selective barrier and develop resistance through target alterations. For example, after Staphylococcus aureus strains became penicillin resistant through the acquisition of a $\beta$-lactamase, methicillin (a $\beta$-lactamase-resistant antibiotic) was

$\uparrow$ Present address: National Institutes of Health/NIAID, Ft Detrick, Frederick, MD 21701, USA.

Abbreviation: PBP, penicillin-binding protein. 
introduced in the treatment of resistant strains. Intrinsic resistance to methicillin soon followed (Brown \& Reynolds, 1980). This resistance was accompanied by an increase in this organism's PBP 3 levels or by the appearance of a new PBP (PBP 2a or 2') which was methicillin inducible (Hartman \& Tomasz, 1984; Rossi et al., 1985; Ubukata et al., 1985). In both cases, these PBPs exhibited a decreased affinity for all $\beta$-lactams.

Studies on intrinsic resistance in Neisseria gonorrhoeae showed that a mutation that changed outer membrane penetration only accounted for a two- to fourfold increase in penicillin resistance, whereas the total increase was in the 100- to 200-fold range (Guymon et al., 1978). Examination of the PBPs (three in total) showed an alteration in PBP 2 that accounted for an additional eightfold increase in resistance (Dougherty et al., 1980). An additional mutation affected both PBPs 1 and 2 (Dougherty, 1984).

In Streptococcus pneumoniae, genetic transformations of a susceptible laboratory strain with DNA from a highly penicillin-resistant South African clinical isolate yielded a series of step-level resistant (progressively higher increments of resistance) strains. Each step was accompanied by the appearance of new or the disappearance of old PBPs as well as alterations in the binding affinities of the PBPs (Hakenbeck et al., 1980; Zighelboim \& Tomasz, 1980). However, the donor and recipient possessed vastly different initial PBP profiles, and while detailed analyses of affinity changes have been described (Handwerger \& Tomasz, 1986), the precise number of genetic and/or physiological steps in the acquisition of resistance has not been determined.

Streptococcus faecium can possess two types of intrinsic resistance. The first, as described above, involves alterations in PBP affinity. The second appears to be novel, detected as changes in the staining intensity of membrane proteins and by an increase in PBP 5 binding, possibly reflecting increasing amounts of a slow-binding, low-affinity penicillin-binding enzyme (Fontana et al., 1983; Daneo-Moore et al., 1983).

In an effort to better understand the alterations in PBPs that accompany the acquisition of penicillin resistance, we have created a series of penicillin step-level resistant transformants of Streptococcus sanguis V288 (Challis strain) using the DNA of a laboratory-derived penicillinresistant multistep mutant of the same strain. By kinetic analysis we could identify the number of transformation events required to achieve any one level of resistance (Goodgal, 1961). Using single-step transformants, we could then deduce whether a single transformation event results in the alteration of one, or more than one, PBP.

\section{METHODS}

Strains. S. sanguis V288 (Challis, biotype I), kindly provided by F. Macrina, Medical College of Virginia VCU, Richmond, Va., USA, was used as the wild-type strain. The minimum inhibitory concentration (MIC) of penicillin for this strain was $0.015 \mu \mathrm{g} \mathrm{ml}^{-1}$. Successive platings of $S$. sanguis V288 (approx. $10^{9}$ cells) on increasing concentrations of penicillin G yielded $S$. sanguis S.55D (MIC $0.80 \mu \mathrm{g} \mathrm{ml}^{-1}$ ). In each successive plating, the concentration of penicillin $\mathrm{G}$ was increased by $0.02 \mu \mathrm{g} \mathrm{ml}^{-1}$ and the plate was incubated for $48 \mathrm{~h}$, after which the entire surface of the plate was harvested using an inoculating loop, and plated on the next penicillin concentration. No mutagens were used - S.55D was a multistep spontaneous mutant. The steps were not characterized.

Media. Organisms were routinely grown in Todd-Hewitt broth (Difco) supplemented with $2 \%(\mathrm{w} / \mathrm{v})$ glucose (THG) or additionally with $0 \cdot 1 \%$ (w/v) cysteine (THGc). All strains were stored in THGc with $30 \%(\mathrm{v} / \mathrm{v})$ glycerol at $-80^{\circ} \mathrm{C}$.

DNA isolation. We used a glycine-enhanced lysis procedure to isolate bacterial DNA (Reider \& Macrina, 1976). Prewarmed THGc ( $200 \mathrm{ml})$ was added to a $50 \mathrm{ml}$ overnight culture. After $2 \mathrm{~h}$ incubation, $7.5 \mathrm{~g}$ glycine was added. Cells were harvested, washed, and resuspended in $25 \%(\mathrm{w} / \mathrm{v})$ glucose in ET buffer ( $5 \mathrm{mM}-\mathrm{EDTA}, 10 \mathrm{~mm}$-Tris, pH 8.5). Lysozyme ( $25 \mathrm{mg}$ in $2.5 \mathrm{ml} \mathrm{ET}$ ) was added and the suspension incubated for $1 \mathrm{~h}$ at $37^{\circ} \mathrm{C}$. Pronase ( $15 \mathrm{mg}$ in $2.5 \mathrm{ml} \mathrm{ET}$, self-digested, $37^{\circ} \mathrm{C}, 1 \mathrm{~h}$ ) was added and incubation continued for $30 \mathrm{~min}$, followed by the addition of $0.4 \mathrm{mg} \mathrm{RNAase}$ and $0.7 \mathrm{ml} 20 \%(\mathrm{w} / \mathrm{v}) \mathrm{SDS}$. The mixture was heat-shocked at $60{ }^{\circ} \mathrm{C}$ for $5 \mathrm{~min}$ and incubated for an additional $2 \mathrm{~h}$ at room temperature. One volume of ice-cold $95 \%(\mathrm{v} / \mathrm{v})$ ethanol was added. The DNA was wound on a glass rod, washed successively with $80 \%, 70 \%$ and $50 \%(\mathrm{v} / \mathrm{v})$ ethanol and resuspended overnight in $1 \times \operatorname{SSC}(0.015 \mathrm{M}$-sodium citrate, $0.15 \mathrm{M}$-sodium chloride). Deproteination was completed through three phenol/chloroform/isoamyl alcohol $(25: 24: 1$, by vol.) extractions. The final solution was dialysed against $1 / 10$ TES (50 mM-Tris, 5 mM-EDTA, 50 mm-sodium chloride, pH 8.0) and the concentration of DNA determined spectrophotometrically. 
Genetic transformation. This was basically by the method of Lawson \& Gooder (1970). A frozen glycerol culture of the recipient $(100 \mu \mathrm{l})$ was appropriately diluted (usually $\left.1: 10^{4}\right)$ and grown for $1 \mathrm{~h}$ in THGc supplemented with $10 \%(\mathrm{v} / \mathrm{v})$ horse serum to induce competence. The standard transformation procedure used $4 \mu \mathrm{g}$ DNA, but subsequent hit-kinetics experiments used a range of $0 \cdot 01-4.0 \mu \mathrm{g}$ DNA. The DNA (in $100 \mu \mathrm{l}$ ) was added to $330 \mu \mathrm{l}$ of the recipient culture. After $2 \mathrm{~h}$, portions were diluted and plated on penicillin plates. Transformants were isolated after $24 \mathrm{~h}$ incubation in a candle jar and characterized by MIC replica plating (see below). Transformation frequency was calculated as the number of transformant c.f.u. divided by the number of viable cells at the time of DNA addition.

In preliminary experiments (data not shown) it was found that $2 \mathrm{~h}$ was sufficient to express resistance, and that the addition of DNAase $15 \mathrm{~min}$ after DNA addition had no substantial effect on the kinetics of transformation.

MIC determinations. Three methods were used to determine MIC.

(i) Transformants were initially characterized by being plated to a non-selective medium (THG with $2 \%$, w/v, agar) and incubated for $24 \mathrm{~h}$, after which they were velvet replica-plated to penicillin-containing plates. Isolates with the desired MIC were then picked from the non-selective plate, diluted in broth, single-colony passaged three times on the 'characteristic' concentration of penicillin, and tested for maintenance of the desired MIC.

(ii) The strain was grown in THGc to a density of $10^{7}$ cells $\mathrm{ml}^{-1}$, and then dilutions were plated on various concentrations of penicillin G. Survivors were scored as a percentage of the total c.f.u. $\mathrm{ml}^{-1}$ on non-selective plates. The concentration supporting the growth of $90 \%$ of the organisms is approximately $0.5 \times$ the MIC.

(iii) The MIC was thrice verified by the macro-broth dilutions method using THGc medium (Washington \& Sutter, 1980).

The MICs obtained for all strains did not vary with procedure.

Membrane (envelope) preparation. Cells were grown in 1 litre of THGc to an adjusted optical density, AOD, of 600 at $675 \mathrm{~nm}$ measured in a Coleman model 14 spectrophotometer [1 AOD unit $\equiv 0 \cdot 39 \mu \mathrm{g}$ dry wt of cells ml-1 (Toennies \& Gallant, 1949)], at which time they were harvested, washed, and resuspended in $10 \mathrm{ml}$ $10 \mathrm{~mm}$-sodium phosphate buffer ( $\mathrm{pH} 7 \cdot 0$ ) and frozen in a dry ice/ethanol bath for storage. After defrosting for $5 \mathrm{~min}$ at room temperature, the cell suspension was combined with $20 \mathrm{ml}(35 \mathrm{~g})$ of glass beads $(0 \cdot 10-0 \cdot 12 \mathrm{~mm})$ and the cells were disintegrated in a Bead-Beater with an ice-water jacket (Biospec Products). The procedure involved seven $20 \mathrm{~s}$ bursts with $5 \mathrm{~min}$ intervals to ensure sufficient cooling. The lysate was treated with $200 \mu$ l DNAase $\left(0.5 \mathrm{mg} \mathrm{ml}^{-1}\right)$ and passed through a coarse-grade sintered glass filter to remove the beads. The filtrate was centrifuged $(81000 \mathrm{~g}, 30 \mathrm{~min}$, Beckman Instruments $50 \mathrm{Ti}$ rotor) and resuspended in $1.5 \mathrm{ml}$ buffer. Microscopic examination revealed no whole cells. Portions were frozen in a dry ice/ethanol bath and stored at $-20^{\circ} \mathrm{C}$ until needed for the PBP assay.

Penicillin-binding assay. Membranes $(60 \mu \mathrm{l})$ were added to $20 \mu \mathrm{l}$ of appropriately diluted $\left[{ }^{3} \mathrm{H}\right]$ benzylpenicillin and incubated for $15 \mathrm{~min}$ at $37^{\circ} \mathrm{C}$. Preliminary experiments (data not shown) indicated that the binding of penicillin by $S$. sanguis V288 was linear for 20-30 min. The reaction was stopped by the addition of $5 \mu 1$ unlabelled penicillin $\mathrm{G}\left(100 \mathrm{mg} \mathrm{m}^{-1}\right)$. The sample was immediately prepared for SDS-PAGE by the addition of $50 \mu 1$ sample buffer [120 mM-Tris/HCl buffer, pH 6.8, $2 \%(\mathrm{w} / \mathrm{v}) \mathrm{SDS}, 20 \%(\mathrm{v} / \mathrm{v})$ glycerol, $0.001 \%$ bromophenol blue], 2 mercaptoethanol $(10 \mu \mathrm{l})$ and $10 \%(\mathrm{w} / \mathrm{v}) \operatorname{SDS}(10 \mu \mathrm{l})$. The samples were boiled for $2 \mathrm{~min}$ and centrifuged for $5 \mathrm{~min}$ at $12000 \mathrm{~g}$ (Fisher Micro-centrifuge 235).

$S D S-P A G E$. The procedure was basically that of Laemmli \& Favre (1973). Supernatants from the binding assay (approx. $200 \mu \mathrm{g}$ protein) were loaded on a $7.5 \%(\mathrm{w} / \mathrm{v})$ acrylamide separating gel with a $4.0 \%$ stacking gel. The gel was run at room temperature for $21.0 \mathrm{~h}$ at $10 \mathrm{~mA}$, then fixed in acetic acid/2-propanol/water $(1: 1: 8$, by vol.), stained with $0 \cdot 275 \%$ Coomassie blue, and destained with acetic acid/methanol/water $(1: 1: 8$, by vol.). The gel was then prepared for fluorography by the method of Laskey \& Mills (1975). Dehydration was accomplished through washes with DMSO and the gel was impregnated with PPO $(25 \%, \mathrm{w} / \mathrm{v}$, in DMSO $)$ and rehydrated. Alternatively, the gel was treated with Amplify (Amersham). A Hoeffer slab dryer was used to vacuum-dry the gel. Kodak XOmat AR film was placed over the gel in a light-tight cassette and exposed for various periods of time at $-70^{\circ} \mathrm{C}$. The developed film was scanned with a soft-laser densitometer (Biomed Instruments) and areas under the resulting peaks were measured and plotted after corrections for protein loaded on the gel and comparison to a wildtype standard which was included in every experiment (see below).

Quantification of binding. Gel and fluorograph results were standardized from experiment to experiment in the following manner. The amount of protein loaded on the gel was determined by the method of Lowry. Every gel run contained a lane with V288 wild-type membranes bound with $12.5 \mu \mathrm{g}\left[{ }^{3} \mathrm{H}\right]$ benzylpenicillin $\mathrm{ml}^{-1}$. The densitometric data were corrected for the protein content, and PBP 2 of the wild-type lane was assigned a densitometric value of 4.00. All sample values were then related to this value.

It was found that a $6 \mathrm{~d}$ exposure of the gel to film allowed optimum visualization of the five major PBPs of $S$. sanguis V288 wild-type with minimal background from non-specific binding as determined by measurements with the soft-laser densitometer.

To ensure proper quantification of the binding of radiolabelled penicillin, a calibration gel was made as follows. From a standard binding assay using a final concentration of radiolabelled penicillin of $12.5 \mu \mathrm{g} \mathrm{ml}^{-1}$, different 
volumes of the final supernatant (and therefore different amounts of protein: 50,100,150,200,250 and $300 \mu \mathrm{g}$, as determined by the Lowry method) were loaded on a standard-type SDS-PAGE gel. After a $6 \mathrm{~d}$ exposure of film to the gel, PBPs 1, 2, 3, and 5 showed a linear relationship of protein concentration versus fluorographic density measurement in the $150-250 \mu \mathrm{g}$ protein range. However, the major binding protein, PBP 4 , did not respond in a linear fashion. To account for a possible undermeasurement of PBP 4 values, the film was exposed for $1 \mathrm{~d}$. In such an exposure, PBP 4 did respond linearly, as did PBP 2, but the values for PBPs 1, 3, and 5 were too low for precise measurement. Therefore, PBP 4 binding values were determined as follows. A fluorograph from a $6 \mathrm{~d}$ exposure was subjected to soft-laser densitometry to obtain values for PBPs 1, 2, 3, and 5, and a fluorograph from a $1 \mathrm{~d}$ exposure was then measured to obtain values for PBPs 2 and 4. The ratio of PBP 4 values to PBP 2 values from the $1 \mathrm{~d}$ exposure must hold true for the $6 \mathrm{~d}$ exposure; hence the PBP 4 value was calculated from the product of the $1 \mathrm{~d}$ ratio and the $6 \mathrm{~d}$ PBP 2 value. Pre-flashing of films was found unnecessary for quantification of bound tritium radioactivity.

Only protein amounts from 150 to $250 \mu \mathrm{g}$ were used in any experiment. In most cases, approximately $200 \mu \mathrm{g}$ of protein was loaded on the gels.

Chemicals. Penicillin G and pronase were obtained from Calbiochem, lysozyme from Boehringer-Mannheim, DNAase and RNAase from Millipore, electrophoresis materials from BRL, and miscellaneous chemicals from Fisher Scientific. Tritiated penicillin G $\left(\left[{ }^{3} \mathrm{H}\right]\right.$ benzylpenicillin ethylpiperidinium salt, $\left.851 \mathrm{GBq} \mathrm{mmol}^{-1}\right)$ was a generous gift of Merck and Co., Inc., Rahway, NJ, USA.

\section{RESULTS}

\section{Transformation of $S$. sanguis}

DNA from the laboratory-derived resistant organism, S.55D (MIC $0.80 \mu \mathrm{g}$ penicillin $\mathrm{G} \mathrm{ml}^{-1}$ ), was used to transform the wild-type $S$. sanguis V288 (MIC $0.01 \mu \mathrm{g} \mathrm{ml}^{-1}$ ) (Table 1). Transformants were isolated on 0.03 and $0.10 \mu \mathrm{g}$ penicillin $\mathrm{G} \mathrm{ml} \mathrm{m}^{-1}$. Two hundred isolates from the $0.03 \mu \mathrm{g} \mathrm{ml}^{-1}$ plate (the first step) were replica-plated on concentrations of penicillin ranging from 0.02 to $0.25 \mu \mathrm{g} \mathrm{ml}^{-1}$. This experiment yielded a bimodal distribution of transformant MICs (Fig. 1), with peaks of MICs at 0.04 and $0.125 \mu \mathrm{g}$ penicillin $\mathrm{ml}^{-1}$. According to this analysis, about half of the transformants isolated on $0.03 \mu \mathrm{g}$ penicillin $\mathrm{ml}^{-1}$ exhibited a resistance level associated with a second step (at approximately $0.10 \mu \mathrm{g} \mathrm{ml}^{-1}$ ).

Transformants that grew with $0.03 \mu \mathrm{g}$ penicillin $\mathrm{ml}^{-1}$ but not with higher concentrations (designated ss.03T), were purified (see Methods), and were transformed again with S.55D DNA to a resistance level of $0.10 \mu \mathrm{g} \mathrm{ml}^{-1}$ (ss.10T, second step) (Table 1). Transformation of ss.10T yielded organisms resistant to $0.25 \mu \mathrm{g} \mathrm{ml}^{-1}$ (ss.25T, third step) (Table 1). Similarly, an ss.55T isolate was obtained from transformation of ss.25T with S.55D DNA (Table 1). Survival curves

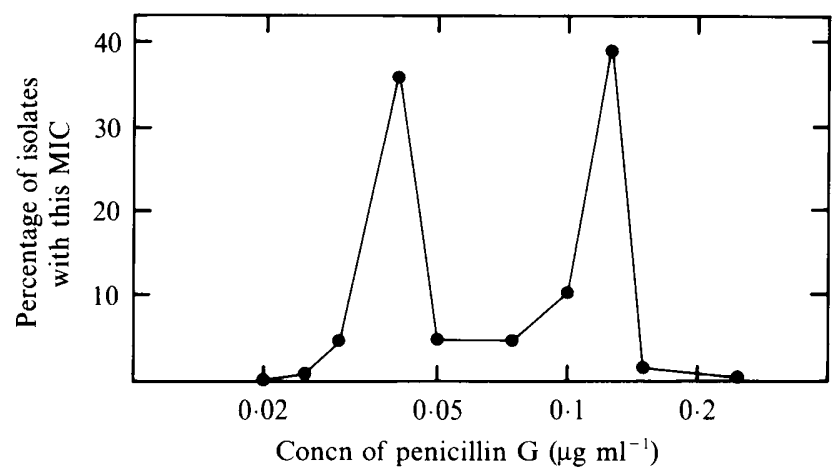

Fig. 1. Distribution of resistance levels of transformants isolated on $0.03 \mu \mathrm{g}$ penicillin $\mathrm{G} \mathrm{ml}^{-1}$. Two hundred transformants from the $0.03 \mu \mathrm{g} \mathrm{ml}^{-1}$ plate were velvet replica-plated to increasing concentrations of penicillin $\mathrm{G}\left(0.02-0.25 \mu \mathrm{g} \mathrm{ml}^{-1}\right)$. The concentration at which an individual isolate no longer showed growth was designated as its MIC. The value plotted at any concentration of penicillin G excludes isolates with any other MIC. The abscissa units are expressed as [(number of isolates with a particular concentration for an MIC)/200] $\times 100$. 


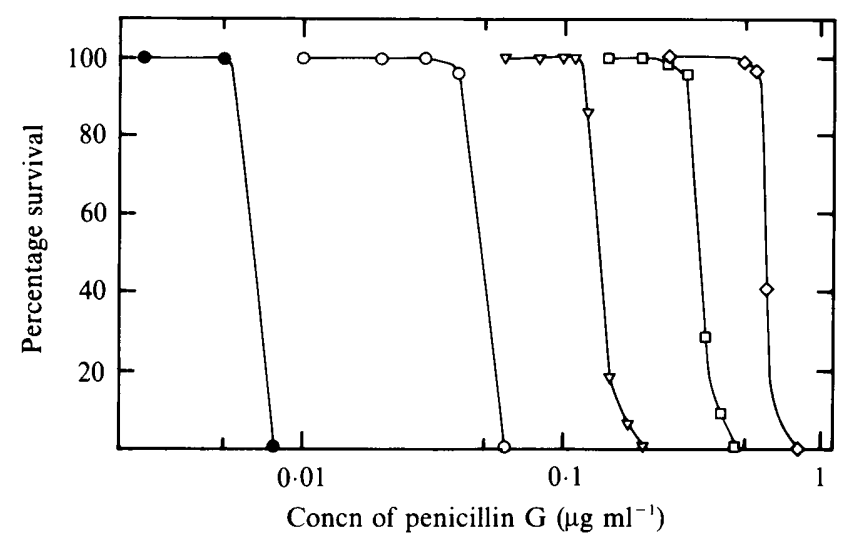

Fig. 2. Survival curves of transformation step isolates. Dilutions of exponentially growing cultures (approx. $10^{7}$ c.f.u. $\mathrm{ml}^{-1}$ ) of transformant isolates (in THGc with no antibiotic) were plated onto increasing concentrations of penicillin G. Survival is expressed as [(number of c.f.u. $\mathrm{ml}^{-1}$ on penicillin)/(number of c.f.u. $\mathrm{ml}^{-1}$ on non-selective plates) $] \times 100$. $\odot$, V288 wild type; $O$, ss.03T; $\nabla$, ss.10T; $\square$, ss.25T; $\diamond$, ss.55T.

Table 1. Transformation of V288 wild-type and step-level isolates to penicillin resistance

Horse-serum-induced competent recipients were incubated in THGc with $4.0 \mu \mathrm{g}$ donor DNA for $2 \mathrm{~h}$ prior to selection on penicillin plates. The DNA donor in all cases was a laboratory-derived penicillinresistant (MIC $0.8 \mu \mathrm{g}$ penicillin $\mathrm{G} \mathrm{ml}^{-1}$ ) $S$. sanguis Challis strain designated $\mathrm{S} .55 \mathrm{D}$. The recipients were representative strains of each step-level of resistance (unable to survive at a concentration of penicillin greater than that on which they were isolated). See Results for a complete explanation of the derivation of step-level isolates.

$\begin{array}{lcc}\text { Recipient } & \begin{array}{c}\text { Concn of } \\ \text { penicillin } \mathrm{G} \\ \left(\mu \mathrm{g} \mathrm{ml}^{-1}\right)\end{array} & \begin{array}{c}\text { Transformation } \\ \text { frequency* }\end{array} \\ \text { V288 } & 0.03 & 2.5 \times 10^{-2} \\ & 0.10 & 2.6 \times 10^{-2} \\ \text { ss.03T } & 0.25 & 0 \\ & 0.10 & 1.1 \times 10^{-2} \\ \text { ss.10T } & 0.25 & 1.6 \times 10^{-4} \\ & 0.55 & 0 \\ \text { ss.25T } & 0.25 & 3.0 \times 10^{-3} \\ & 0.55 & 0\end{array}$

* Transformation frequency was calculated as the number of transformants per number of viable cells at the time of DNA addition. The values presented are means of three replicate determinations on separate occasions.

of V288, step transformants, and S.55D organisms on various concentrations of penicillin G are shown in Fig. 2. The steep nature of the curves suggests that each transformant represents one step in the acquisition of penicillin resistance.

\section{Comparison of transformation frequencies with a different marker}

The decrease in transformation frequencies that accompanied the acquisition of penicillin resistance (Table 1) posed an interesting question. Was there a general decrease in the transformability of these organisms or was the lowered frequency associated with the penicillin resistance marker itself? To answer this question, a rifampicin-resistant derivative of S.55D was obtained by spontaneous mutant selection (MIC $>1.0 \mu \mathrm{g}$ rifampicin $\mathrm{ml}^{-1}$ ). Its DNA was 
Table 2. Transformation of V288 wild-type and step-level isolates to penicillin and rifampicin resistance

\begin{tabular}{|c|c|c|c|c|}
\hline \multirow[b]{2}{*}{ Recipient } & \multirow{2}{*}{$\begin{array}{l}\text { Concn of } \\
\text { penicillin } G \\
\left(\mu \mathrm{g} \mathrm{ml}^{-1}\right)\end{array}$} & \multicolumn{2}{|c|}{ Transformation frequency* } & \multirow{2}{*}{$\begin{array}{c}\text { Ratio } \\
b / a \dagger\end{array}$} \\
\hline & & $\operatorname{Pen}^{r}(a)$ & $\operatorname{Rif}^{\mathrm{r}}(b)$ & \\
\hline V288 & 0.03 & $1.4 \times 10^{-1}$ & $4.2 \times 10^{-2}$ & \\
\hline ss.03T & $0 \cdot 10$ & $1.3 \times 10^{-1}$ & $2 \cdot 2 \times 10^{-1}$ & \\
\hline ss.10T & $0 \cdot 25$ & $1.3 \times 10^{-2}$ & $9.4 \times 10^{-2}$ & \\
\hline ss. $25 \mathrm{~T}$ & 0.55 & $2.5 \times 10^{-4}$ & $5.6 \times 10^{-2}$ & \\
\hline
\end{tabular}

* Calculated as described in Table 1. The values are means of two replicate determinations on separate occasions.

+ The ratio of the transformation frequencies of the two markers was calculated to determine whether there was a decrease in transformability of the strains or whether reduced transformation frequencies were associated with the penicillin resistance marker (see Results).

extracted and used to transform the step-level isolates and the V288 wild-type to the next penicillin step as well as to rifampicin resistance (Table 2). Once again, the transformation of ss.10T and ss. $25 \mathrm{~T}$ to higher levels of penicillin resistance occurred at a lower frequency than the transformation of the V288 wild-type and ss.03T. However, transformation to rifampicin resistance of all of these organisms occurred at similar frequencies $\left(4 \cdot 2 \times 10^{-2}\right.$ to $\left.2.2 \times 10^{-1}\right)$.

\section{Transformation hit-kinetics analysis}

The bimodal distribution of penicillin resistance levels in the original $0.03 \mu \mathrm{g} \mathrm{ml}^{-1}$ isolates (Fig. 1) suggested the possibility that at least two genes were being transformed (one for each level of resistance). In addition, the similar frequency in the transformation of the wild-type to resistance levels of 0.03 and $0.10 \mu \mathrm{g} \mathrm{ml}^{-1}\left(2.5 \times 10^{-2}\right.$ and $2.6 \times 10^{-2}$, respectively; see Table 1) raised the possibility of linkage between these genes. To investigate this possibility further, transformations of $S$. sanguis V288 were conducted using various amounts of S.55D DNA $(0 \cdot 01-$ $4 \cdot 0 \mu \mathrm{g}$ ). Analysis of the slope of the log-log plot of transformants per ml versus amount of DNA gives the number of DNA fragments taken up by the cells that yield successful transformational events (Goodgal, 1961). Transformation of V288 to the first step requires a single 'hit' as evidenced by a slope of 1 (Table 3). Transformation of V288 to the second step gives a slope greater than 1, indicating that more than one hit is required for expression of this level of resistance. That the slope is 1.26 to 1.58 and not 2 suggests that both genes are, in some cases, on the same piece of DNA (as would be the case if the two genes were linked).

Transformation of ss.03T to a resistance level of $0.10 \mu \mathrm{g} \mathrm{ml}^{-1}$ (first step to second step) using DNA from ss.10T should represent a single step, and should be a single-hit event. As expected, the slope was approximately $1(0 \cdot 94)$. However, using the same ss.10T DNA to transform V288 to $0 \cdot 10 \mu \mathrm{g} \mathrm{ml}^{-1}$ (two steps) gave a slope greater than $1(1 \cdot 15)$ (Table 3). The difference in these values is statistically significant $(P=0 \cdot 006)$.

To further check the hypothesis that the genes giving resistance to 0.03 and $0.10 \mu \mathrm{g} \mathrm{ml}^{-1}$ are linked, we did an experiment using mechanically sheared and unsheared S.55D DNA (Fig. 3). Unsheared DNA gave a slope of 1.41 , whereas sheared DNA gave a slope of 1.80 (much closer to the theoretical maximum value of $2 \cdot 0$ ), consistent with the involvement of two linked genes which were separated by the shearing process.

\section{Penicillin-binding proteins}

S. sanguis possesses five major PBPs of molecular masses $86,83 \cdot 5,78 \cdot 5,72$ and $47 \mathrm{kDa}$ as determined by mobility in SDS-PAGE. We number the PBPs 1 to 5 in order of decreasing size (Fig. 4). PBPs 3, 4, and 5 show a major band and a minor band, of slightly lower apparent 


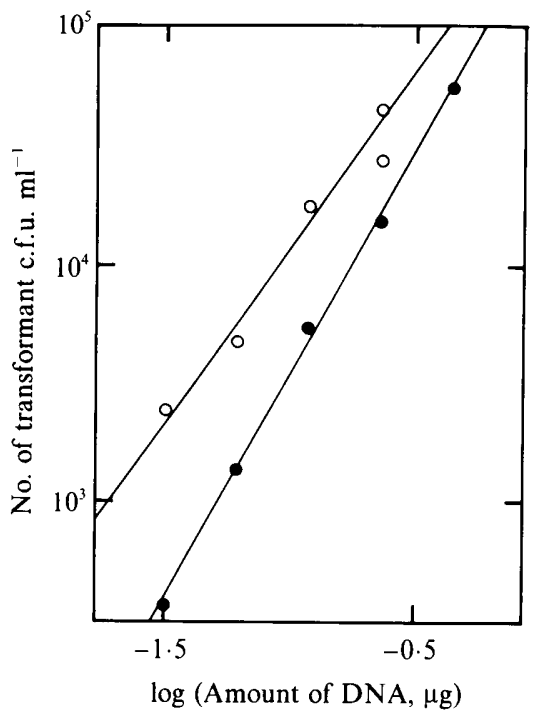

Fig. 3. Transformation hit-kinetics analysis. Various amounts of sheared $(O)$ or unsheared $(O)$ S.55D DNA were used to transform V288 wild-type (see Methods). Transformants were selected on penicillin $\mathrm{G}, 0.03 \mu \mathrm{g} \mathrm{m}^{-1}$. Shearing of DNA was accomplished by passing it 30 times through a 25 -gauge needle. Slopes, determined by linear-regression analysis of a $\log -\log$ plot of transformant c.f.u. $\mathrm{ml}^{-1}$ versus $\mu \mathrm{g}$ DNA used, were: unsheared, 1.41 ; sheared, $1.80(P<0.01)$.

\section{Table 3. Results of transformation hit-kinetics experiments}

Competent cells were incubated with various amounts of donor DNA $(0 \cdot 01-4.0 \mu \mathrm{g})$. The slope of a $\log -\log$ plot of the number of transformants $\mathrm{ml}^{-1}$ versus the amount of DNA yields the number of DNA fragments taken up by the cell resulting in a successful transformation event (see Results).

$\begin{array}{lcccc}\text { DNA donor } & \text { Recipient } & \begin{array}{c}\text { Concn of } \\ \text { penicillin G } \\ \left(\mu \mathrm{g} \mathrm{m}^{-1}\right)\end{array} & \begin{array}{c}\text { Expected } \\ \text { slope* }\end{array} & \begin{array}{c}\text { Observed } \\ \text { slope } \dagger\end{array} \\ \text { S.55D } & \text { V288 } & 0.03 & 1.00 & 1.04 \\ \text { S.55D } & \text { V288 } & 0.03 & 1.00 & 1.02 \\ \text { Ss.10T } & \text { ss.03T } & 0.10 & 1.00 & 0.94 \\ \text { S.55D } & \text { V288 } & 0.10 & >1 & 1.26 \\ \text { S.55D } & \text { V288 } & 0.10 & >1 & 1.47 \\ \text { S.55D } & \text { V288 } & 0.10 & >1 & 1.58 \\ \text { ss.10T } & \text { V288 } & 0.10 & >1 & 1.15\end{array}$

* Expectation based on the hypothesis that two genes exist, one conferring resistance to $0.03 \mu \mathrm{g} \mathrm{ml}^{-1}$, one to $0 \cdot 10 \mu \mathrm{g} \mathrm{ml}^{-1}$.

† The slope was obtained by linear regression analysis using seven points.

molecular mass. There was no change in the molecular mass of any of the PBPs with increasing level of resistance. The fluorograph shown in Fig. 4 is presented for qualitative not quantitative analysis. Quantification of the fluorographs involved consideration of fluorograph incubation time and protein content as well as comparison to standardized samples. The minor bands of PBPs 3, 4, and 5 detected with very long film exposure varied in intensity from preparation to preparation and were shown in a series of experiments to be breakdown products of the respective major bands. They were therefore pooled in densitometric analysis. 


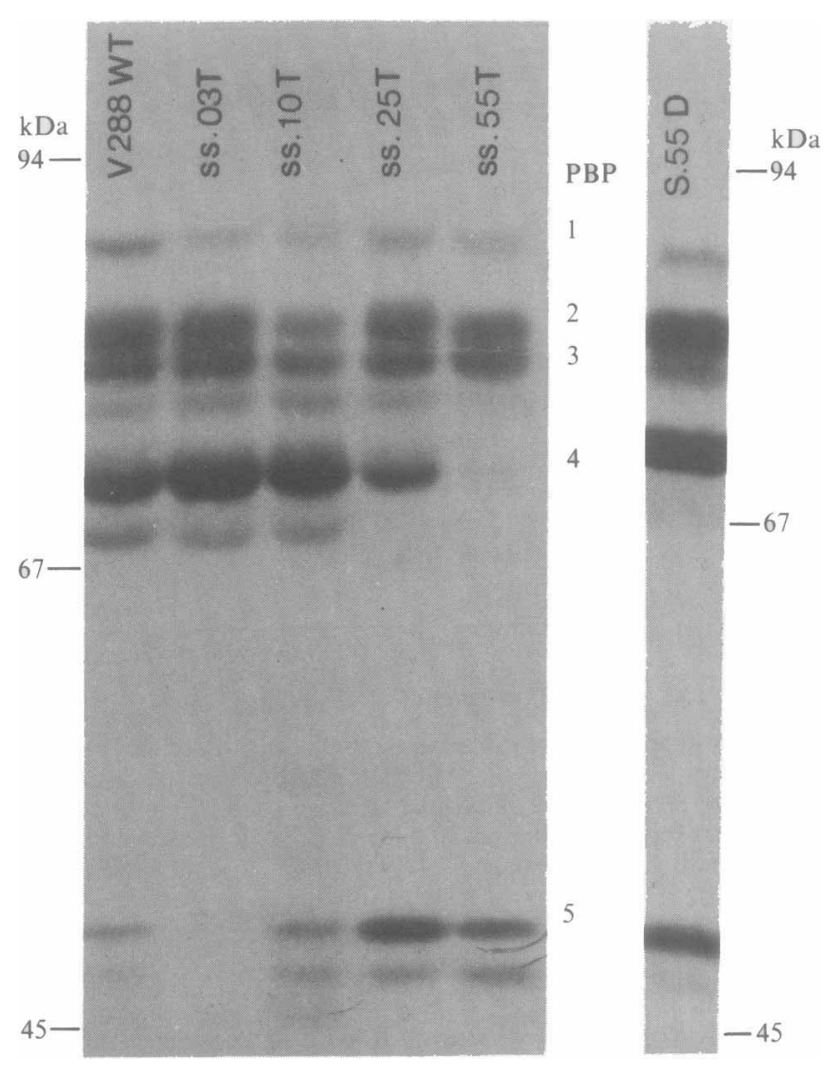

Fig. 4. Fluorograph of $S$. sanguis strains. PBPs were detected by incubation of membrane-wall preparations with $\left[{ }^{3} \mathrm{H}\right]$ benzylpenicillin, SDS-PAGE and subsequent fluorography (see Methods). All lanes contain approximately equal amounts of protein $(200 \mu \mathrm{g})$. The apparent molecular masses of the five major PBPs are 86, 83.5, 78.5, 72 and $47 \mathrm{kDa}$. The donor, S.55D, possesses PBPs of the same molecular mass as the recipients (lane from different gel). Quantitative differences are described in the text and Fig. 5.

Fig. 5 presents the results obtained by the quantification procedure described in Methods. In the wild-type, V288, PBP 2 binds at the lowest concentration of antibiotic and becomes saturated at $12.5 \mu \mathrm{g}$ penicillin $\mathrm{ml}^{-1}$. PBP 4 has the highest saturation value by far of all of the PBPs (note different scale for the PBP 4 plot in Fig. 5). Comparison of the PBPs of $S$. sanguis V288 and of the resistant DNA donor S.55D (Figs 4 and 5) shows a decrease in affinity of binding of penicillin by PBPs 1, 2 and 3 in the resistant strain. PBP 4 has a great decrease in affinity and saturation value. There is no apparent alteration in PBP 5.

We also looked for differences associated with each step level of resistance (Fig. 6). The first step resulted in a decrease in binding affinity of all five PBPs. The decreases in PBPs 4 and 5 were quite pronounced. The second step (ss.10T) showed no further decreases in PBP affinity, although PBP 5 increased back to levels similar to the wild-type. The third (ss.25T) and fourth (ss.55T) steps were characterized by further decreases in the binding of penicillin by PBP 4 . In the final step, PBP 4 was barely detectable, and only at the highest concentrations of antibiotic.

In a time course assay, there was an average increase of $30 \%$ in the amount of radiolabelled penicillin bound to individual PBPs when the binding incubation period was increased from 15 to $60 \mathrm{~min}$ (data not shown). The data did not suggest any mechanisms of resistance due to a slowkinetic binding PBP such as that found in $S$. faecium, where differences are about $500 \%$. 

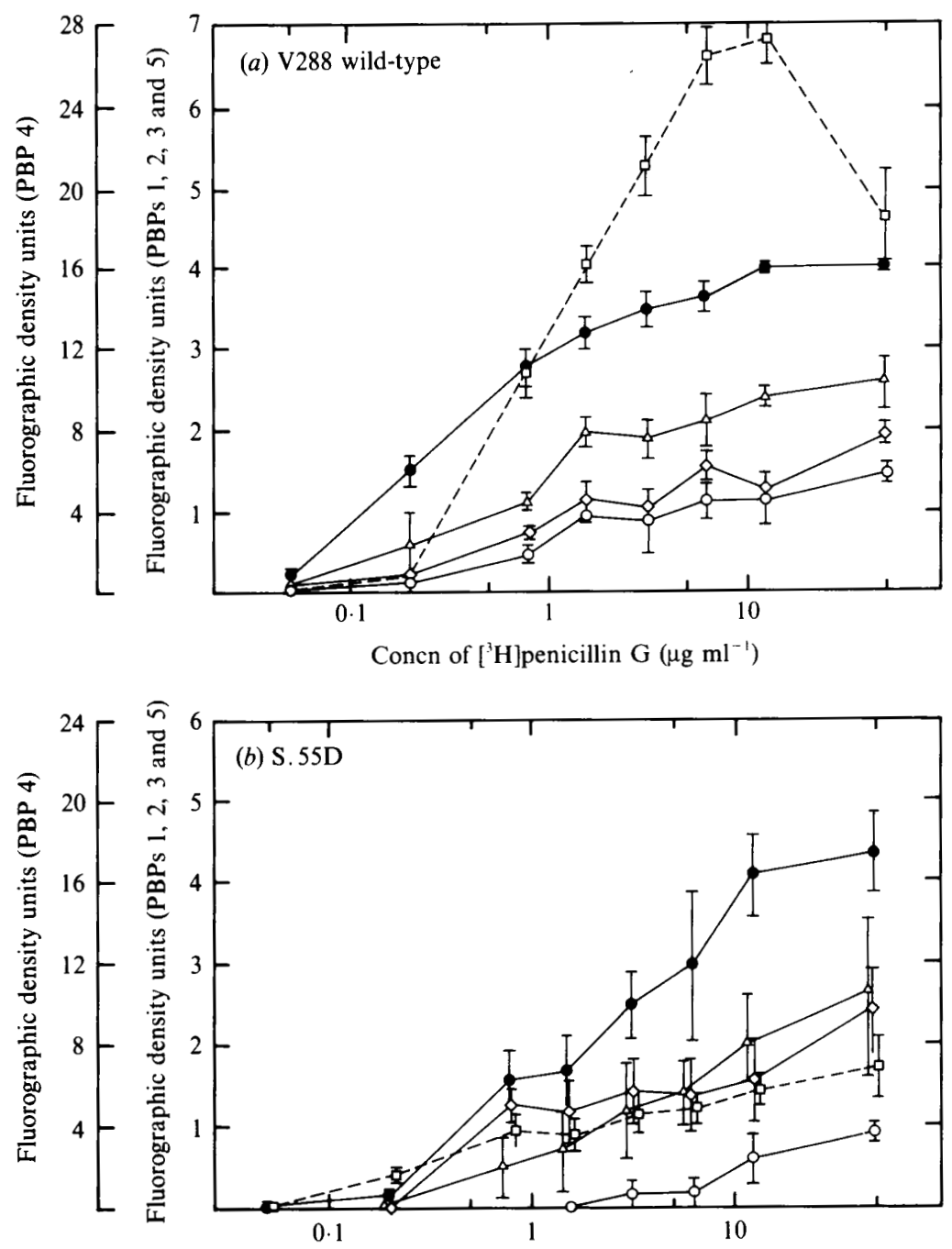

Concn of $\left[{ }^{3} \mathrm{H}\right]$ penicillin $\mathrm{G}\left(\mu \mathrm{g} \mathrm{ml}^{-1}\right)$

Fig. 5. Densitometric analyses of V288 wild-type (a) and S.55D (b) PBP banding on fluorographs versus concentration of $\left[{ }^{3} \mathrm{H}\right]$ benzylpenicillin. Density units were determined by measuring the areas under peaks in a densitometric scan of the fluorographs, correcting for amount of protein loaded, and standardizing against the wild-type results (see Methods). Error bars represent the standard deviation of values from three separate preparations and gels. Data points are staggered horizontally to allow for clear presentation of error bars (PBP 2 points are on actual values). $O$, PBP 1 ;, PBP $2 ; \triangle$, PBP 3 ; $\square$, PBP 4 (note different scale); $\diamond$, PBP 5.

\section{Membrane protein patterns}

PBPs rarely constitute more than $1 \%$ of the total membrane protein of the cell (Blumberg $\&$ Strominger, 1974), preventing their visualization without radiolabelling. Examination of the Coomassie-blue-stained SDS-polyacrylamide gels of our step-resistant organisms failed to show consistent differences in membrane proteins. 

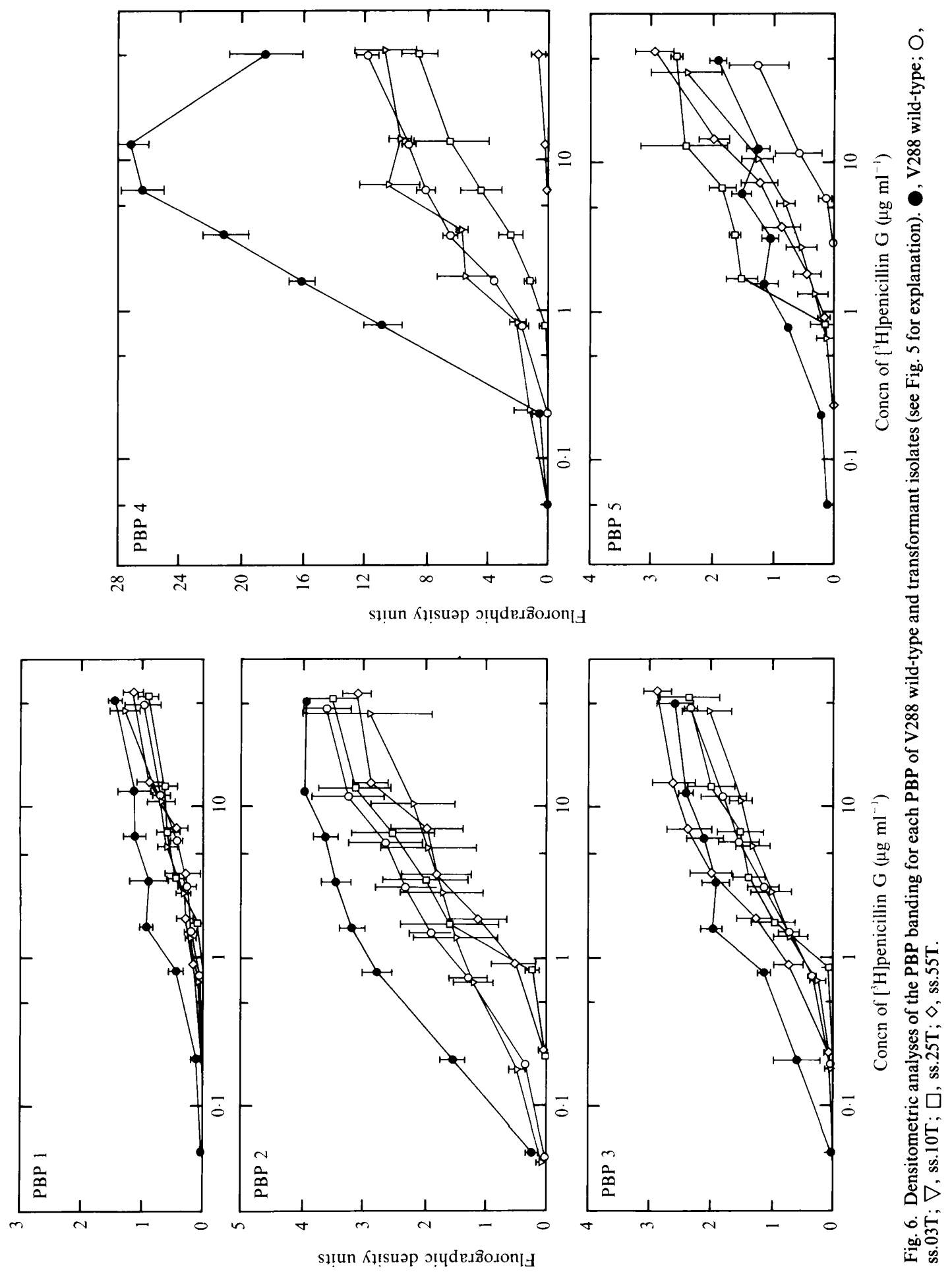


\section{DISCUSSION}

In this report, we describe the transformation of a penicillin-susceptible strain of $S$. sanguis V288 to step-levels of penicillin resistance using a resistant DNA donor. That resistance to $\beta$ lactam antibiotic in streptococci occurs in increments had already been described by Shockley $\&$ Hotchkiss (1970) and by Butler \& Smiley (1970). As in those studies using $S$. pneumoniae, penicillin resistance in $S$. sanguis appears to be multigenic.

The present report suggests that at least two of the genes responsible for the observed transformation of $S$. sanguis V288 to step-levels of penicillin resistance are linked. The initial evidence for linkage of resistance to 0.03 and $0.10 \mu \mathrm{g}$ penicillin $\mathrm{ml}^{-1}$ was that the transformation frequencies for both levels were similar (approx. $2.5 \times 10^{-2}$ ) (Table 1). Further evidence of possible linkage was obtained from transformation hit-kinetics experiments, which showed that transformation to a resistance level of $0.03 \mu \mathrm{g}$ penicillin $\mathrm{G} \mathrm{ml}^{-1}$ required a single 'hit' or DNA fragment (Table 3), whereas transformation to a resistance level of $0.10 \mu \mathrm{g} \mathrm{ml}^{-1}$ required more than one hit (a range of 1.25 to 1.58 hits). The observation that this requirement was not for two fragments (as would be expected with two separate unlinked genes) further supported the linkage hypothesis (since in some transformation events, both genes resided on a single fragment taken up by the cell). Additional hit-kinetics experiments using DNA from ss. $10 \mathrm{~T}$ (the second step-level isolate) gave similar results: single-step transformants of resistance (ss.03T to $0 \cdot 10 \mu \mathrm{g} \mathrm{ml}^{-1}$ ) required one hit ( 0.94 fragments) and two-step transformations (V288 wild-type to $\left.0.10 \mu \mathrm{g} \mathrm{ml}^{-1}\right)$ required more than one hit (1.15 fragments) (Table 3). Finally, mechanically shearing the donor DNA prior to transformation increased the fragment requirement from 1.41 to 1.80 , closer to the 'ideal' value of 2.0 expected from two different fragments providing the two steps of resistance (Fig. 3).

The frequency of transformation of ss.03T to penicillin resistance levels of $0.10 \mu \mathrm{g} \mathrm{ml}^{-1}$ and $0.25 \mu \mathrm{g} \mathrm{ml}^{-1}\left(10^{-2}\right.$ versus $\left.10^{-4}\right)$ indicated that each level of resistance appeared to require an additional unlinked gene. The isolation of ss. $25 \mathrm{~T}$ and ss.55T at decreasing frequencies $\left(3 \times 10^{-3}\right.$ and $1.9 \times 10^{-3}$, Table 1) was shown to be due to the expression of the penicillin resistance phenotype, rather than to a general decrease in transformability of the cells (Table 2). A decrease in the frequency of transformation to high levels of penicillin resistance has also been observed in S. pneumoniae (Tomasz et al., 1984) and Bacillus subtilis (Buchanan \& Strominger, 1976). The difficulties in the expression of the penicillin resistance phenotype may be due to problems associated with the insertion of an altered PBP into the membrane, to growth-inhibiting changes in membrane structure, or to the presence of other copies of the susceptible genotype acting in a dominant manner. Possibly, the expression of high-level penicillin resistance requires a longer phenotypic lag.

A most important observation in this study was that single-step changes in the levels of penicillin resistance were associated with changes in binding affinities of more than one PBP. This suggests that the various transformants may not have mutations in the structural genes coding for the PBPs themselves. The mutations may have affected gene expression, antibiotic accessibility, membrane composition, or the processing and insertion of PBPs into the membrane, all of which can affect PBP binding affinities or levels. A similar observation has been made in Pseudomonas aeruginosa, where reduction in binding affinities of several PBPs accompanied penicillin resistance acquired after a single gene mutation (Godfrey \& Bryan, 1982). That the multi-PBP alteration at a single step of resistance is not due to more than one DNA molecule taken up during transformation was demonstrated by the hit-kinetics analysis.

The decrease in PBP 4 that accompanied the development of penicillin resistance in $S$. sanguis is particularly notable, for it was consistent and dramatic. The PBP 4 of the high-level transformant (ss.55T) was barely detectable. Due to the limitations of the assay system, this decrease may be due to either reduced numbers of PBP 4 molecules or production of a modified molecule which binds penicillin poorly. The modified protein may or may not be able to function at a level of activity corresponding to wild-type levels. A decrease in PBP 4 activity may be compensated by increased synthetic activities of other PBPs, since there appears to be redundancy in PBP activity (Brown \& Reynolds, 1980). Severely decreased PBP 4 activity does not result in substantial reduction in the growth rate of ss.55T in THGc medium (doubling time 
$36 \mathrm{~min}$, versus $32 \mathrm{~min}$ for V288 wild-type and for transformants ss.03T, ss.10T and ss.25T). It may be interesting in future studies to attempt to detect low-affinity PBPs by utilizing anti-PBP antibodies (Hakenbeck et al., 1986).

The alterations in PBP 5 did not follow the expected gradual decrease (or increase) with increased penicillin resistance. There did appear to be a decrease in affinity associated with resistance, but saturation values increased across the final three step-levels. After the initial decrease in ss.03T, PBP 5 was apparently restored to wild-type levels. This may indicate that there is an absolute requirement for a certain level of PBP 5 activity for growth and survival of cells in higher concentrations of penicillin. Alternatively, PBP 5 may be a protein which is able to compensate for reduced activities in other PBPs. Thus the increase in resistance from 0.03 to $0 \cdot 10 \mu \mathrm{g} \mathrm{ml}^{-1}$ may involve a deregulation or 'amplification' of an altered PBP 5 serving to compensate for the reduced PBP 4.

A further point of interest was the fact that the highest step-level resistant transformant, ss.55T, although having the same level of penicillin resistance as the DNA donor S.55D, had a different PBP pattern. In theory, the series of steps of resistance obtained in this study may be one of several possible series. Acquisition of a different first-step 'alteration' may potentiate the development of further resistance via an alternative series of transformable mutations. It is probable that the series of mutations that led to the isolation of the DNA donor S.55D is not reflected in the step-level resistances of the transformants, since the PBPs of the transformants do not approach the pattern of S.55D (Fig. 4). A less likely possibility is that the altered binding levels of S.55D are due to its very slow growth (doubling time $64 \mathrm{~min}$, versus $32 \mathrm{~min}$ for the wildtype V288).

In summation, we have described a series of genetic and biochemical changes associated with increasing penicillin resistance, and have shown that these changes result in multiple alterations in binding activities of the PBPs at each step. The novel aspect of this study is the demonstration that a 'single-hit' transformation event can result in alterations in the affinity of more than one PBP. In addition, a progressive decrease in the penicillin-binding affinity and in penicillin binding was found to occur through a series of presumably single transformation events.

We would like to thank G. Pozzi for helpful comments and suggestions, Dr P. J. Cassidy of Merck \& Co., Inc., for a generous gift of $\left[{ }^{3} \mathrm{H}\right]$ labelled penicillin $\mathrm{G}$, and $\mathrm{G}$. Harvey for expert editorial work.

This work was supported by Pubic Health Service grant DE 05180 from the National Institutes of Health.

\section{REFERENCES}

Blumberg, P. M. \& Strominger, J. L. (1974). Interaction of penicillin with the bacterial cell: penicillin-binding proteins and penicillin-sensitive enzymes. Bacteriological Reviews 38, 291-335.

Brown, D. F. J. \& REYNOLDS, P. E. (1980). Intrinsic resistance to $\beta$-lactam antibiotics in Staphylococcus aureus. FEBS Letters 122, 275-278.

Buchanan, C. E. \& Strominger, J. L. (1976). Altered penicillin-binding components in penicillin-resistant mutants of Bacillus subtilis. Proceedings of the National Academy of Sciences of the United States of America 73, 1816-1820.

Butler, L. O. \& SMiley, M. B. (1970). Characterization by transformation of an ampicillin-resistant mutant of pneumococcus. Journal of General Microbiology 61, 189-195.

Daneo-Moore, L., Pucci, M., Zito, E. T. \& Ferrero, M. (1983). Studies of a beta-lactam resistance in Streptococcus faecium. In The Target of Penicillin, pp. 493-498. Edited by R. Hakenbeck, J.-V. Höltje \& H. Labischinski. Berlin: Walter de Gruyter.

DOUGHERTY, T. J. (1984). Intrinsic resistance: penicillin target alterations and effects on cell wall synthesis. In Microbiology - 1984, pp. 398-401.
Edited by L. Leive \& D. Schlessinger. Washington, DC: American Society for Microbiology.

Dougherty, T. J., Koller, A. E. \& Tomasz, A. (1980). Penicillin-binding proteins of penicillinsusceptible and intrinsically resistant Neisseria gonorrhoeae. Antimicrobial Agents and Chemotherapy 18, 730-737.

Fontana, R., Canepari, P. \& Satta, G. (1983). The role of a protein that binds penicillin with slow kinetics in physiology response to penicillin of Streptococcus faecium ATCC 9790. In The Target of Penicillin, pp. 531-536. Edited by R. Hakenbeck, J.-V. Höltje \& H. Labischinski. Berlin: Walter de Gruyter.

Godfrey, A. J. \& Bryan, L. E. (1982). Mutation of Pseudomonas aeruginosa specifying reduced affinity for penicillin G. Antimicrobial Agents and Chemotherapy 21, 216-223.

GoOdGaL, S. H. (1961). Studies on transformation of Haemophilus influenzae. IV. Linked and unlinked transformations. Journal of General Physiology 45, 205-228.

Guymon, L. F., Walstad, D. L. \& Sparling, P. F. (1978). Cell envelope alterations in antibiotic- 
sensitive and -resistant strains of Neisseria gonorrhoeae. Journal of Bacteriology 136, 391-401.

HakenbeCK, R., TARPaY, M. \& Tomasz, A. (1980). Multiple changes of penicillin-binding proteins in penicillin-resistant clinical isolates of Streptococcus pneumoniae. Antimicrobial Agents and Chemotherapy 17, 364-371.

HaKenbeck, R., Ellerbrok, H., Briese, T., HandWERGER, S. \& TOMASZ, A. (1986). Penicillin-binding proteins of penicillin-susceptible and -resistant pneumococci: immunological relatedness of altered proteins and changes in peptides carrying the $\beta$ lactam site. Antimicrobial Agents and Chemotherapy 30, 553-558.

HANDWERGER, S. \& TOMASZ, A. (1986). Alterations in kinetic properties of penicillin-binding proteins of penicillin-resistant Streptococcus pneumoniae. Antimicrobial Agents and Chemotherapy 30, 57-63.

HaRTMan, B. J. \& Tomasz, A. (1984). Low-affinity penicillin-binding protein associated with $\beta$-lactam resistance in Staphylococcus aureus. Journal of Bacteriology 158, 513-516.

LAEMMLI, U. K. \& FAVRe, M. (1973). Maturation of the head of bacteriophage T4. I. Packaging events. Journal of Molecular Biology 80, 575-599.

LASKeY, R. A. \& Mills, A. D. (1975). Quantitative film detection of ${ }^{3} \mathrm{H}$ and ${ }^{14} \mathrm{C}$ in polyacrylamide gels by fluorography. European Journal of Biochemistry 56, 335-341.

Lawson, J. W. \& Gooder, H. (1970). Growth and development of competence in Group $\mathrm{H}$ streptococci. Journal of Bacteriology 120, 820-825.

REIDER, J. L. \& MACRINA, F. L. (1976). Plasmid DNA isolation in Streptococcus mutans: glycine-enhanced lysis. In Proceedings: Microbial Aspects of Dental Caries (A Special Supplement to Microbiology $A b$ stracts), vol. 3, pp. 725-736. Edited by H. M. Stiles, W. J. Loesche \& T. C. O'Brien. Washington, DC: Information Retrieval.

Rossi, L., Tonin, E., Cheng, Y. R. \& Fontana, R. (1985). Regulation of penicillin-binding protein activity: description of a methicillin-inducible penicillin-binding protein in Staphylococcus aureus. Antimicrobial Agents and Chemotherapy 27, 828-831.
Shockley, T. E. \& Hotchkiss, R. D. (1970). Stepwise introduction of transformable penicillin resistance in pneumococcus. Genetics 64, 397-408.

SPRATT, B. G. (1977). Properties of the penicillinbinding proteins of Escherichia coli. European Journal of Biochemistry 72, 341-352.

SPRATT, B. G. (1983). Penicillin-binding proteins and the future of $\beta$-lactam antibiotics. Journal of General Microbiology 129, 1247-1260.

ToenNies, G. \& Gallant, D. L. (1949). The relationship between photometric turbidity and bacterial concentration. Growth 13, 7-20.

Tomasz, A., Zighelboim-Daum, S., Handwerger, S., LIV, H. \& QIAN, H. (1984). Physiology and genetics of intrinsic beta-lactam resistance in pneumococci. In Microbiology - 1984, pp. 393-397. Edited by L. Leive \& D. Schlessinger. Washington, DC: American Society for Microbiology.

Ubukata, K., Yamashita, N. \& Konno, M. (1985). Occurrence of a $\beta$-lactam-inducible penicillin-binding protein in methicillin-resistant staphylococci. Antimicrobial Agents and Chemotherapy 30, 57-63.

Washington, J. A., II \& SutTer, V. L. (1980). Dilution susceptibility test: agar and macro-broth dilution procedures. In Manual of Clinical Microbiology, 3rd edn, pp. 453-458. Edited by E. H. Lennette, A. Balows, W. J. Hausler, Jr \& J. P. Truant. Washington, DC: American Society for Microbiology.

Waxman, D. J. \& Strominger, J. L. (1983). Penicillinbinding proteins and the mechanisms of action of $\beta$ lactam antibiotics. Annual Review of Biochemistry 52, 825-869.

Zighelboim, S. \& Tomasz, A. (1980). Penicillinbinding proteins of multiply antibiotic-resistant South African strains of Streptococcus pneumoniae. Antimicrobial Agents and Chemotherapy 17, 434-442.

ZimmermaN, W. (1980). Penetration of $\beta$-lactam antibiotics into their target enzymes in Pseudomonas aeruginosa: comparison of a highly sensitive mutant with its parent strain. Antimicrobial Agents and Chemotherapy 18, 94-100. 